\title{
Notes on Sugar-cane Diseases.
}

\author{
BY \\ F. A. F. C. WENT, \\ Professor of Botany in the University of Utrecht: formerly Director of the \\ West Java Sugar Experiment Station. \\ With Plate XXVI.
}

M ASSEE'S paper on Trichosphaeria Sacchari ${ }^{1}$ induced me to make a renewed investigation of some of the parasites affecting the sugar-cane in the island of Java. I shall give the results of this investigation here, at the same time as those formerly arrived at, but which till now had only been published in the Dutch language ${ }^{2}$. Mr. Barber forwarded to me alcohol specimens of diseased sugar-cane from the West Indies, and his kindness enabled me to determine the identity of several of the West Indian parasites of the cane with those existing in Java.

I shall begin first of all by describing two fungus-diseases, the red smut and the pineapple-disease.

\section{Red Smut (Colletotrichum falcatum).}

Red smut affects the interior of the stems of the sugar-cane. Externally no trace of its existence can be discovered, except when the canes are very badly attacked, in which case the

1 Annals of Botany, Vol. vii. No. XXVIII, December, I 893.

${ }^{2}$ Went, Het Rood Snot; and Went, De Ananasziekte van het Suikerriet: Mededeelingen van het Proefstation West Java: both published in Archief voor de Javasuiker-industrie, I, I893 ; also Bot. Centralbl., 59, I894 : also J. H. Wakker, De Ananasziekte of het Zwart Rot in Oost-Java, Mededeelingen van het Proefstation Oost-Java, N. Serie, No. 7 ; Archief voor de Javasuiker-industrie, I894, p. 209.

[Annals of Botany, Vo1. X. No. XL. December, 1896.] 
leaves die: but as soon as the stems are split longitudinally, red spots are to be seen on the section. These spots are purple, but the colour is not equally distributed, it being darker in one place than in another. Very characteristic of this disease are white blotches in the interior of the red spots, these white blotches extending mostly in a direction transverse to the stalk. Another peculiarity is only to be seen on transverse sections, namely, that in the direction of the periphery the distinction between the dark red diseased tissue and the sound portion of the stem is very sharply defined. The periphery of the stem is generally not attacked; this explains the fact that the symptoms of the disease are not seen externally, because the vascular bundles communicating with the leaves at the top are not affected. These red spots are to be found either in the middle of a joint or near the node; but in either case careful examination is sure to show that the cane has been damaged in these places, either by some insect, like the moth-borer, or by some fungus-disease. Badly diseased canes are often red-spotted in the interior from the base to the top; sometimes brownish spots may be seen at the nodes.

With regard to the macroscopic characteristics of the disease, there only remains to be said that vascular bundles emerging from the diseased spots are red-coloured and gummy along a certain distance from the diseased place. I may here take the opportunity to state that wherever a part of the stem of a sugar-cane has been damaged, either by man or by animal or vegetable parasites, the vascular bundles communicating with the damaged spot become gummy and redcoloured. This is not only the case in Java, but from the diseased canes received from Mr. Barber I was able to conclude that sugar-cane in the West Indies behaves in exactly the same manner. A description of these gumming vascular bundles has been given by Valeton ${ }^{1}$. I would here repeat the statement that Bacteria have nothing to do with this

1 Th. Valeton, Bijdrage tot de Kennis der Serehziekte: Mededeelingen van het Proefstation Oost-Java, I891. 


\section{Went.-Notes on Sugar-cane Diseases.}

gumming ${ }^{1}$, and I do so because I have several times read the assertion that I should have found the Australian gummingdisease, as described by $\mathrm{Cobb}^{2}$, in Java. Now, only a few months ago I observed some phenomena here which might be identical with the Queensland disease, ascribed by Cobb to the influence of parasitic Bacteria. But the gummy redcoloured vascular bundles found in all diseases of the cane have nothing to do with this, and are not due to any action of Bacteria.

If we turn now to the microscopic examination of the disease, it will be seen that the cells in the diseased spots are filled with the mycelium of a fungus. The hyphae contain a great many small oil-drops, soluble in alcohol and ether. Frequently in older blotches the fungus can no longer be found in the centre of the diseased spots, but here the oil-drops very generally have persisted, so that the direction of the former hyphae is still manifest. It is very easy to cultivate this fungus by bringing sections of diseased canes into a damp place. In from twelve to twenty-four hours a beautiful mycelium grows out of the diseased spots; this mycelium is at first almost white, but afterwards its colour becomes greyish or smoky, perhaps between Nos. 2 and 39 of Saccardo ${ }^{3}$ : if the hyphae are moistened, the colour changes and becomes light olive-green (No. 39, Saccardo). The mycelium is again characterized by its oil-drops. After a few days' growth chlamydospores are formed, sometimes in the middle of a filament (Fig. 3), but mostly at the end of a hypha (Figs. I, 2). They contain large oil-drops and have a somewhat irregular form; their cell-wall is coloured dark olivegreen.

In making cultures of the fungus on nutrient solutions or agar-agar, these chlamydospores are produced in great

1 Went, De Serehziekte : Mededeelingen van het Proefstation West Java. Archief voor de Javasuikerindustrie, I, I893; Bot. Centralbl. 59, I894.

${ }^{2}$ N. A. Cobb, Plant Diseases and their Remedies; Diseases of the Sugar-cane. Department of Agriculture, N. S. W. Sydney, I893.

${ }^{3}$ P. A. Saccardo, Chromotaxia sen Nomenclator Colorum. Ed. altera, 1894. 
numbers, but very few conidia are to be found. In order to get these it is necessary either to seek in cracks of diseased canes or to allow a piece of longitudinally split diseased cane to dry slowly. In the latter case, after twenty-four to forty-eight hours, some black streaks appear running lengthwise of the cane on the cut surfaces. On examining these by the aid of the microscope, it is clear that they are stromata; from each stroma spring a great number of dark-brown hairs, and at the foot of these the conidia are found (Fig. 4). Figs. 5 and 6 give a more magnified view of two such hairs, with the conidia forming cells at their base. Each hair is divided into cells. Very often the case of Fig. 6 occurs, viz. that the top of the hair remains uncoloured. Fig. 7 represents three stages in the formation of conidia on their basidia; in $c$ the conidium is almost ripe, and has already assumed its characteristic sickle-shaped form. This may be still better seen in Fig. 8 , where a ripe conidium is represented; the conidium is colourless and contains a protoplast which is highly refringent. Fig. 9 shows some other forms of conidia, which sometimes may be found; the difference in form is mostly due to the position in which these conidia are seen. I have already remarked that in nutrient solutions very few conidia are developed; in that case there are no brown hairs to be found, or only here and there a single one. Fig. Io shows a mycelium-filament of such a culture, which has given off several short branches; these will again develop branches, which will be the basidia on which the conidia are found.

The conidia germinate very easily in nutrient solutions; Fig. II shows three stadia of germinating conidia. By cultivating one single conidium in a hanging-drop, the evidence may easily be got that the mycelium emanating from it later on, forms the above-mentioned chlamydospores; the result therefore is that these and the conidia belong to the same fungus.

From the above-mentioned characters it will be seen that the fungus belongs to the genus Colletotrichum; I have named it Colletotrichum falcatum because of the shape of the conidia. 


\section{Went.-Notes on Sugar-cane Diseases.}

The fungus will be sufficiently recognizable I am sure if I give some measurements : hairs, 100-200 $\times 4 \mu$; conidia, $25 \times 5 \mu$; basidia, (about) $20 \times 8 \mu$ (but the size of the basidia is very variable).

Every cane diseased by red smut contained the mycelium of Colletotrichum falcatum, and as during the last four years I have examined a very large number of diseased canes, it seemed very probable that this fungus might be the cause of the disease: But this had to be proved. With this object I made incisions in sound canes and inoculated them with mycelium from pure cultures of Colletotrichum falcatum; the wound was shut off from the air by a little tinfoil. After ten days some of the canes treated in this manner were cut longitudinally; it could be very distinctly seen that round the wound the cane had become diseased by red smut. After twenty days the whole joint was diseased, showing the characteristic red spots with white blotches, and under the microscope the cells were seen to be filled with the mycelium of Colletotrichum falcatum. Incisions made in sound canes, without inoculating with the fungus, did not produce the disease; only the dead cells round the wound became coloured red, as is always the case when a cell of the sugar-cane dies.

We may conclude therefore that Colletotrichum falcatum is the cause of red smut. But it is only a wound-parasite; sound canes, which have not been damaged, cannot be attacked by the fungus, with the exception of very young parts of the stem. This is practically of no importance, as these parts are protected by the surrounding sheaths of the leaves.

The attack of the fungus may cause serious damage, owing to the deterioration of the canes and the diminution of the sugar. At the Tjomal estate, where the disease was first detected in 1892 , at the beginning of the grinding season samples are taken from all the various cane-fields and cut longitudinally; all the canes of those fields which prove to be attacked in any serious degree by red smut are reaped and crushed before the others, because the disease spreads very 
soon over the canes that are still sound. It will be very difficult to combat the disease in any other way; it is impossible of course to remove and destroy the diseased canes, for we cannot tell by the outward appearance if canes are attacked by Colletotrichum falcatum. But of course everything may be done to preserve the cane from injury, more especially by borers.

As already stated, the disease was first detected in 1892 at the Tjomal estate; from thence it is spreading gradually over more estates, especially those situated to the west of Tjomal. Now it is very interesting that the fungus exists in other parts of Java, in those too where the disease is yet unknown. There Colletotrichum falcatum is a simple saprophyte on dead cane-leaves. Hence it seems that there are special circumstances which induce this saprophyte to become a woundparasite.

The fungus has also been found outside of Java. Massee ${ }^{1}$ attributes to it the so-called root-disease in the West Indies, but gives no evidence whatever for his opinion. I received the fungus from the West Indies, so I could identify it with Colletotrichum falcatum from Java; and according to my experience about the fungus and the disease it causes at Java (not only in the purple Java cane but in other varieties such as Louzier too) I think it extremely improbable that the so-called root-disease-a disease which looks very much like the 'sereh' in Java-is caused by Colletotrichum falcatum. As this fungus is generally a saprophyte, its mere presence on diseased canes is no evidence for its being the cause of the disease.

In conclusion, I may add that I have cultivated Colletotrichum falcatum on very different nutrient solutions for several years-since I 892 ; that I have searched for other forms of this fungus on diseased canes, but have never got anything but conidia and chlamydospores. Only in two cultures on agar-agar with cane-juice and $\frac{1}{2} \%$ peptone did I get

\footnotetext{
${ }^{1}$ Bulletin of Miscellaneous Information, Royal Gardens, Kew, 1893, p. 347.
} 
a yeast-form, but as I have not been able to get this in more cases, and as I have never seen under the microscope that conidia of Colletotrichum falcatum form yeast-cells, I think it is probable that these yeast-cells were an impurity which had somehow found its way into the cultures.

\section{PineapPle-Disease (Thielaviopsis ethaceticus).}

In most cases this disease only attacks cuttings, though it may be found in the stems of half-grown or full-grown cane too, if these are damaged; but this last mode of occurrence of the disease is very rare.

Diseased cuttings are blackish on the cut surface; on dividing them longitudinally the interior shows a red or crimson colour, if they are only slightly diseased, whereas the more serious symptoms are a black colour in the centre of the crimson-coloured part. When diseased cuttings are planted, or when the disease breaks out after the cuttings have been planted, the buds do not sprout, or die shortly after having sprouted. Very characteristic is the odour of diseased canes, as soon as they are cut; it reminds one of different fruits, especially pineapples (hence the name).

In examining the diseased tissue under the microscope, it will be seen that the red colour is occasioned by dead cells, of which the cell-walls have taken this colour; in the interior of these cells is to be found the colourless mycelium of a fungus. The black colour is occasioned by the conidia of this same mould.

It is very easy to cultivate the fungus; these conidia soon germinate in a drop of any nutrient solution; some stages of germinating conidia are represented in Fig. I 2.

Cultures of the fungus remain snowy-white so long as only vegetative mycelium is developed; but very soon (twelve to twenty-four hours) afterwards the colour grows darker, somewhat olive-green or dark green (between Nos. 34 and 39 of Saccardo), in consequence of the formation of conidia. These conidia exist in two kinds, which I call 
macro- and microconidia. The macroconidia are situated in apical chains at the end of short branches of the mycelium (Fig. I3). Their cell-walls are of a dark olive-green colour. Their contents are generally not to be seen, owing to the colouration of the cell-walls and to the number of large oildrops in the interior (Fig. 14). Only where these oil-drops are very small and where the colouration of the cell-wall is lighter, as in Fig. I5, the protoplasm with the vacuoles may be visible. The conidium at the top of the chain very oftenbut not always - is almost spherical, as in Figs. I 3 and I4, the other conidia being more elongated. In Fig. 16 the formation of such a chain is to be seen ; $a$ is the beginning, one conidium has been formed. Under the microscope I was able to observe that the top of the hypha under the conidium formed a new transverse septum, and thus a new conidium was made : $b$ was drawn one and a half hour after $a$; the top conidium had become larger and more spherical : three hours afterwards, in $c$, the apical conidium had become still larger and shows a commencing colour of the cell-wall; two new septa had been formed, being the beginning of the development of a third and a fourth conidium. It results from this that the macroconidia are formed in a basipetal manner.

The microconidia are also produced in chains, but they arise partly in the interior of the conidia-bearing-cell. Fig. I7 shows in $a$ the very first beginning of a conidia-bearing hypha, which is a thick somewhat curved branch of the mycelium. This curve remains in the adult hyphae, as is to be seen in Fig. $17 b$ or Fig. 18 . The number of conidia in a chain may be three or four, but generally is very great, Fig. 18 not being an extreme case at all. Fig. 19, much more magnified, may give an idea of the manner in which these microconidia are formed at the top of a hypha, from which they are afterwards extruded. Three of the conidia are quite free; one is just escaping from the cell-wall $(a)$ of the hypha; another has just been formed, but its basal wall $(b)$ still forms a part of the hypha; another one has its basal wall not yet quite developed $(c)$. These microconidia 
have a rectangular form and are colourless; sometimes they are slightly coloured and more oval, approaching in their form the macroconidia. Fig. 20 gives the tops of three hyphae bearing microconidia; in $a$ the upper part is empty, the microconidia having been shed; in $b$ there is one conidium just escaping from the hypha; in $c$ two microconidia are not yet pushed out.

Macro- and microconidia may be found on branches of the same mycelium filament. In making cultures of macroconidia, both forms of conidia are obtained, just as well as when cultures are begun with microconidia; proving that they belong to the same fungus. Lastly, all sorts of transitory stages between the two forms of conidia may be found: as in Fig. 2I, where $a$ and $b$ represent two stages in the typical formation of a chain of macroconidia, whereas in $c$ it can be seen that the lowest of these macroconidia is being pushed out of the hypha in which it has been formed, just like a microconidium. The size of the microconidia and that of the macroconidia too (but in a less degree) is extremely variable, so that the measurements given here are only approximately true; macroconidia $16-19 \times 10-12 \mu$; microconidia IO-I $5 \times 3.5-5 \mu$; length of the microconidia-bearing hyphae $100-200 \mu$. In order to give an idea of the difference in form and size of the conidia I have delineated in Fig. 22 a group of conidia, as I found it under the microscope.

Though I made a great number of cultures of this fungus I could not detect other organs of reproduction; the same result was got by Wakker, who also has been cultivating the fungus at Pasuruan for some years. The microconidia of the fungus are similar to those described by Zopf for Thielavia basicola $^{1}$, but the macroconidia are very different. I therefore have given the fungus the generic name of Thielaviopsis and call the species in question Thielaviopsis ethaceticus.

It may be easily proved that Thielaviopsis ethaceticus is the cause of the pineapple-disease, by bringing some of the conidia

1 W. Zopf, Ueber die Wurzelbräune der Lupinen, eine neue Pilzkrankheit. Zeitschrift für Pflanzenkrankheiten, Bd. i, I89I, p. 72. 
on to the cut surface of cuttings of the sugar-cane. After two or three days the cuttings exhibit all the symptoms of the disease. The same may be seen by infecting half- or fullgrown cane with the conidia of the fungus through holes previously made. The conidia cannot infect canes through the sound epidermis of the stem, with the exception of the very young white parts of it, which however are naturally protected by the surrounding leaf-sheaths. From these facts it follows that the means of preventing the disease are very simple. They consist in protecting from the air the cut surfaces of cuttings. This is done here by means of tar, previously rendered more liquid by the addition of a little arrack. On estates where this method is employed the disease has ceased to show itself.

The physiological properties of Thielaviopsis are very interesting. It is quite easy to cultivate the fungus on all sorts of nutrient solutions, on potatoes, bananas, \&c. It is a saprophyte, which attacks all sorts of materials containing sugar, such as different fruits, mangoes, pineapples, bananas, \&c. It spreads so easily that it is very difficult to get rid of the fungus where it once exists. In most of these cultures the agreeable odour can be detected. What is the substance possessing this flavour produced by the fungus? In order to determine this, I made a culture of Thielaviopsis in I $\frac{1}{2}$ litre of a sterilized solution, containing $15 \%$ of saccharose, $\mathrm{I} \%$ of peptone, and a little $\mathrm{K}_{3} \mathrm{PO}_{4}$ and $\mathrm{MgSO}_{4}$. After a week the liquor was distilled, and in this distillate the presence of ethyl acetate (and perhaps of very small quantities of other esters) and of ethylic alcohol could be proved. I further made a solution of $1 \%$ peptone in water with very little $\mathrm{K}_{3} \mathrm{PO}_{4}, \mathrm{MgSO}_{4}$ and $\mathrm{CaCl}_{2}$. I divided this solution into seven flasks, and added to them separately the following substances: No. I, nothing; No. 2, cellulose; No. 3, starch; No. 4, 10\% dextrine; No. 5, $10 \%$ glucose; No. $6,10 \%$ saccharose; No. $7,5 \%$ ethylic alcohol. After having sterilized I inoculated with the conidia of Thielaviopsis. In flasks Nos. I, 2 and 3 the fungus developed pretty 
well, but no odour was detected, whereas this was very strong and pronounced in Nos. 4-7. Thus Thielaviopsis ethaceticus can invert dextrine and saccharose into glucose, can make ethylic alcohol out of glucose, and finally can oxidize this alcohol to acetic acid. In old cultures of the fungus, however, the odour disappears, so that it looks as if the ethyl-acetate might afterwards be used and assimilated by the fungus.

A similar fungus has been described by Kayser ${ }^{1}$, and afterwards by Dávalos and Acosta ${ }^{2}$. Kayser has found a yeast and a fungus, which both produce an ester, resembling in its odour the pineapple. The yeast is of no importance whatever here, but the fungus possesses, according to the description and the figure (though both are somewhat indistinct), the same kind of conidia as the microconidia of Thielaviopsis. Macroconidia are not described by Kayser, but the fungus produces ethyl-acetate and small quantities of ethylic alcohol. Other fungi producing conidia similar to the microconidia of Thielaviopsis are Endoconidium and Pyxidiophora.

III.

The paper by Massee on Trichosphaeria Sacchari gave me the impression that what he calls the macro- and microconidia of this fungus are similar to or very little different from the form which I had described as Thielaviopsis ethaceticus. This opinion was confirmed by the material I received from the West Indies containing so-called macro- and microconidia of Trichosphaeria, which could not be distinguished from my Thielaviopsis. This was an inducement for me to study Massee's paper very closely; for if his opinions were right, that these conidia are a form of Trichosphaeria Sacchari and that this fungus has a Melanconium-stage too, there would be an enormous probability that this would be the

1 E. Kayser, Note sur les Ferments de l'Ananas. Ann. de l'Institut Pasteur, I89I, tome v, p. $45^{6}$.

${ }^{2}$ Dávalos y Acosta, Nota sobra el fermento alcohólico de la piña. Crónica Médicoquirurgica de la Habana, I892, No. Io. 
case also with the Java fungus. The measures to prevent the pineapple-disease ought to be altered in that case.

Now it seems to me that Massee has not proved that these two forms of conidia belong to the same fungus as the Melanconium of the cane, nor that these three have an ascigerous stage in Trichosphaeria Sacchari. The reason why the experiments of Massee do not seem conclusive to me is, that he has neglected the first condition of any research into the development of fungi, which condition is, quoting the words of De Bary ${ }^{1}$, 'Das erste Postulat einer morphologisch-entwickelungsgeschichtlichen Untersuchung (ist) der Nachweis der $\mathrm{zu}$ irgend einer Zeit nothwendig vorhandenen organischen Continuität successiver Entwickelungszustände, bei welcher also das später auftretende Glied als ein Theil des nächstfrüheren beginnt.'

Massee found two perithecia of Trichosphaeria Sacchari on much decayed canes received from Barbados, which sprung from a point that had previously borne a crop of microconidia. Massee calls the evidence in favour of a genetic connexion between the perithecia and the microconidia strong, where I might be inclined to speak of it as a very slight indication of the possibility of any such connexion. This supposition according to Massee was proved to be correct when young perithecia were found in a flask containing an old culture produced from a macroconidium. No other evidence whatever is given. Whilst I do not assert that these perithecia and the macroconidia do not belong together, I urge that there is no sufficient evidence to prove this.

Almost the same is the case with regard to the connexion between Melanconium and the macro- and microconidia. In one of three flasks containing cultures of Melanconiumconidia there developed the micro- and macroconidia resembling Thielaviopsis. The most probable explanation of this would have been that these macro- and microconidia were an impurity having by chance entered into the flask; and

1 De Bary, Vergl. Morphologie u. Biologie der Pilze, Mycetozoen und Bacterien, I 884 , p. I 37 . 


\section{Went.-Notes on Sugar-cane Diseases.}

this would be the more probable if they really are identical with Thielaviopsis, because this fungus spreads so very easily that almost any cane sent from Java, however sound it is or attacked by whatever disease, will contain this fungus. No other experiments are given by Massee in support of the view that these fungi are forms of the same species; for the experiment in which a small portion of diseased cane containing hyphae of the Melanconium-stage was introduced into a slit made in a healthy cane where afterwards macroconidia were produced, cannot prove anything, as of course it cannot be known what other organisms had been introduced with the diseased cane.

\section{EXPERIMENTS With MeLANCONiUm-STYlospores.}

I thought it necessary to try some experiments with Melanconium-stylospores. I may premise that Melanconium Sacchari (probably identical with what $\mathrm{Cobb}^{1}$ calls Strumella Sacchari) is called in the West Indies 'rind-fungus.' According to a great many different publications by Barber, Bovell, Hart, Fawcett, \&c. ${ }^{2}$, and to the already mentioned paper of Massee, a serious disease of the cane is attributed to it. This same disease has been described by Cobb in Queensland; whereas Boname ${ }^{3}$ states that Melanconium Sacchari in Mauritius attacks only dead canes. Now here in Java also I have found a Melanconium on the sugar-cane, which so much resembles the fungus from the West Indies that one might be inclined to consider them both as the same species. But the Melanconium in Java is only to be found on dead canes; it is only a saprophyte, and not a wound-parasite, as the form in the West Indies seems to be. Experiments, which I will describe hereafter, have brought me to this conviction. It may be possible that the Melanconium from

${ }^{1}$ Cobb, 1.c., p. 23.

${ }^{2}$ Barbados, Report of Dodds Reformatory, 1892, I893; Supplement to the Leeward Islands Gazette, I893, xxiv ; Bulletin, Botanical Department, Jamaica, 1894, I895 ; Royal Botanic Gardens, Trinidad, Bulletin, I894, I895.

${ }_{3}^{3}$ Colony of Mauritius, Rapport de la Station Agronomique, I894. 
Java, notwithstanding this outward resemblance, is another species than the West Indian Melanconium. I think it however to be much more probable that both fungi belong to the same species, the one being the saprophytic, the other the wound-parasitic form,--somewhat as in the case of Colletotrichum falcatum. It is not quite certain, therefore, that I experimented with the same Melanconium as did Massee, but this is no reason why I should not give the results of my experiments.

I commenced by introducing in the usual way one Melanconium-stylospore into a hanging-drop of a nutrient solution; but I found that this method could not be followed, as most of the stylospores did not germinate, so that an enormous number of hanging-drops would have been necessary in order to get one mycelium. So I introduced a number of stylospores-about ten-into one hanging-drop, and in this manner I could observe germination in about $5 \%$ of the stylospores. But here another difficulty arose. Since these Melanconiumpycnids are only to be found on dead canes, spores of many other saprophytes are introduced into the hanging-drops at the same time. Spores of other Fungi could be eliminated, but Bacteria were a great nuisance, though the nutrient solution was made slightly acid. They were in so far a nuisance as they increased in number very fast and stopped the development of the young Melanconium-mycelia. This was the reason why I did not get ripe conidia in these hangingdrops, and only succeeded in obtaining them after washing the mycelium several times in a sterilized nutrient solution and then putting it on the surface of agar-agar (with nutrient substances). In this manner I was at last successful in getting pure cultures, without any Bacteria.

Fig. 23 shows the germination of two Melanconium-stylospores; sometimes two germ-tubes are developed, sometimes one, as in Fig. 23. Figs. 24 and 25 show a part of a mycelium developed from the Melanconium-stylospore $c$ in different stages of development. This mycelium is beginning to form conidia but did not get beyond the stage of Fig. 25 (stopped by the 
Bacteria mentioned above). However, these two figures will demonstrate that the mode of formation of the conidia is the same as in the agar-cultures. Parts of these have been drawn in Figs. 26, 27 and 28, and more highly magnified in Figs. 29, 30 and $3 \mathrm{I}$. It will be easily seen that the dark black spherical conidia arise by budding on the top of cells with a very refrangent protoplast, which are inflated somewhat like the top of the sporangial filament of Pilobolus. The conidia have a size of $16-14.5 \times 13-12 \mu$; they are often found on dead leaves of the cane. Fig. 32 is a chlamydospore formed in a culture of a Melanconium-stylospore in a hanging-drop; but these chlamydospores are very rare.

Melanconium-stylospores were introduced into slits made in sound canes; the mycelium developed in the dead cells surrounding the slits, but in no case (I made nine experiments) did they attack the healthy tissue of the cane. Exactly the same result followed when I used, not the Melanconium-stylospores, but the mycelium or the large black conidia. On dead leaves of the cane Melanconium-stylospores may germinate; afterwards the black spherical conidia are found on the same spot, but healthy leaves are not attacked by the fungus.

Pieces of sugar-cane were sterilized on the outside by keeping them for some time in a flame; they were then divided longitudinally with a sterilized knife and put into a sterilized glass box. On the cut surface I placed some Melanconiumstylospores. Very soon-within a few days-the spot where I had placed the stylospores became dark red, and a mycelium could be detected with the microscope in the interior of these red cells. Of the ten experiments which I made in this manner, seven were finally destroyed by Bacteria (a complete sterilization of the cane being almost impossible); but in three cases the mycelium developed through the cane as this was dying and gave rise on the surface under the epidermis to the pycnidia of Melanconium; but the stylospores were smaller in size than those which I gathered in the field, though on the other hand they germinated much more easily. 
I got the same result by inoculating sterilized canes with the mycelium or with the large black spherical conidia. In operating with these conidia I succeeded, in two cases out of ten, in obtaining the formation of Melanconium-pycnidia on the surface of the cane, getting thus the complete evidence that these two forms-the stylospores and the large black conidia-belong to the same species. I ought to add that the Melanconium-stylospores never developed on sterilized canes unless I had previously inoculated these canes with the Melanconium-stylospores or with the mycelium developed from them, or with the large black spherical conidia. As the disease attributed to the rind-fungus does not yet exist here, I regret that I am not able to experiment with Melanconium from the West Indies, because I do not wish to introduce this fungus in the living state into Java, considering the danger of infection.

\section{Summary.}

I. Colletotrichum falcatum, being a saprophyte on the leaves of the sugar-cane, can become a wound-parasite under conditions still unknown, and is thus the cause of the disease of the cane at Java called Red Smut.

2. No evidence has been given up to the present that Colletotrichum falcatum is the cause of any other sugar-cane disease.

3. Thielaviopsis ethaceticus is a general saprophyte, behaving sometimes as a wound-parasite, and then causing the pineapple-disease of the sugar-cane in Java.

4. There is some probability that the macro- and microconidia described by Massee as a form of Trichosphaeria Sacchari are identical with Thielaviopsis.

5. At present only micro- and macroconidia of Thielaviopsis are known.

6. Massee has not given sufficient evidence that the ascigerous stage, called Trichosphaeria Sacchari, and the macro- and microconidia, are forms of the same fungus.

7. The evidence given by Massee of these macro- and micro- 


\section{Went.-Notes on Sugar-cane Diseases.}

conidia and the Melanconium-stylospores belonging to the same fungus is insufficient.

8. The Melanconium which is found on dead canes in Java is no parasite; it lives only on canes which are already dead. It follows from this that the Melanconium from Java is perhaps different from that in the West Indies.

9. The stylospores of the Java Melanconium give rise, on germination, to a mycelium producing large black spherical conidia ; these conidia placed on dead canes give again rise to the formation of the pycnidia of Melanconium.

KAGOK-TEGAL, October, I 895 .

\section{EXPLANATION OF FIGURES IN PLATE XXVI.}

Illustrating Professor Went's paper on Sugar-cane Diseases.

Figs. I-II. Colletotrichum falcatum.

Figs. I-3. $\frac{800}{1}$. Mycelium with chlamydospores $(g)$. Figs. I and 2 the chlamydospores at the top of a hypha, Fig. 3 in the middle. Of the cell-contents only the oil-drops have been drawn.

Fig. 4. $\frac{80}{1}$. Stroma (str.) with hairs and conidia (c).

Figs. 5,6 . $\frac{800}{1}$. Young hairs from a stroma; at their bases are basidia, having formed in one case a conidium $c$.

Fig. 7. $\frac{800}{1}$. Three different stages $a, b, c$ in the formation of conidia on the top of the basidia.

Fig. 8. $\frac{800}{1}$. A conidium.

Fig. 9. $\frac{800}{1}$. Three differently-shaped conidia.

Fig. I0. $\frac{8}{1} 0$. Mycelium giving off short branches which will produce the basidia.

Fig. II. $\frac{350}{1}$. Germinating conidia $(c) ; a$, one germ-tube is developing; $b$ and $c$, with germ-tubes on both ends of the conidia.

Figs. I 2-22. Thielaviopsis ethaceticus.

Fig. I 2. $\frac{350}{1}$. Macroconidia germinating.

Fig. 13. $\frac{350}{1}$. Branch of the mycelium with a chain of six macroconidia.

Fig. I 4. $\frac{80}{1} 0$. Chain of three macroconidia with large oil-drops in the interior.

Fig. I5. $\frac{800}{1}$. Chain of six macroconidia not yet fully grown, with very slightly coloured cell-walls and small oil-drops, so that the vacuoles are distinctly visible.

Fig. I6. $\frac{800}{1}$. Successive stages of development of macroconidia : $a$, one conidium is visible; $b$, one and a-half hour later, under the first conidium, which has increased in size, a new one is developed; $c$, three hours later, a third and fourth conidium begin to develop; the first conidium becomes slightly coloured. 
Fig. I $7 . \frac{35}{1} 0 . a$, a very young branch, which will give rise to a long curved hypha with microconidia, like that figured in $b$.

Fig. 18. $\frac{350}{1}$. Branch of the mycelium with chain of microconidia.

Fig. 19. $\frac{s_{0} 0}{1}$. Top of a branch with microconidia: $a$, top of the hypha where one conidium is just escaping ; $c$, transverse cell-wall separating a microconidium, not yet free from the cell-wall of the surrounding hypha; $c$, transverse cell-wall not yet quite formed.

Fig. 20. $\frac{800}{1}$. Three apices of hyphae bearing microconidia: $a$, without conidium; $b$, with a conidium just escaping ; $c$, with two conidia.

Fig. 2I. $\frac{800}{1}$. Three stages of development of microconidia: $a$, with one conidium ; $b$, three hours afterwards, with three quite developed conidia and one not yet ripe; $c$, one hour later, the last-formed basal conidium slides out of the cell-wall of the hypha like a microconidium.

Fig. 22. s $_{1}^{0} 0$. A group of macro- and microconidia of different size.

Figs. 23-32. Melanconium (Sacchari?).

Fig. 23. $\frac{350}{1}$. Stylospores germinating after one day.

Fig. 24. $\frac{350}{1}$. Part of a mycelium developed in three days from the stylospore $c$ in a hanging-drop of wine-must.

Fig. 25. $\frac{35}{1} \frac{0}{2}$ The same as Fig. 24 , but three days later.

Figs. $26,27,28$. $\frac{3}{1}-0$. Mycelium with large black conidia.

Figs. 29, 30. $\frac{8}{1} 00$. Mycelium with large black conidia.

Fig. 3I. $\frac{800}{1}$. Mycelium with branches developing conidia.

Fig. 32. $\frac{35}{1} 0$. Mycelium with chlamydospore $g$. 
Annals of Botany

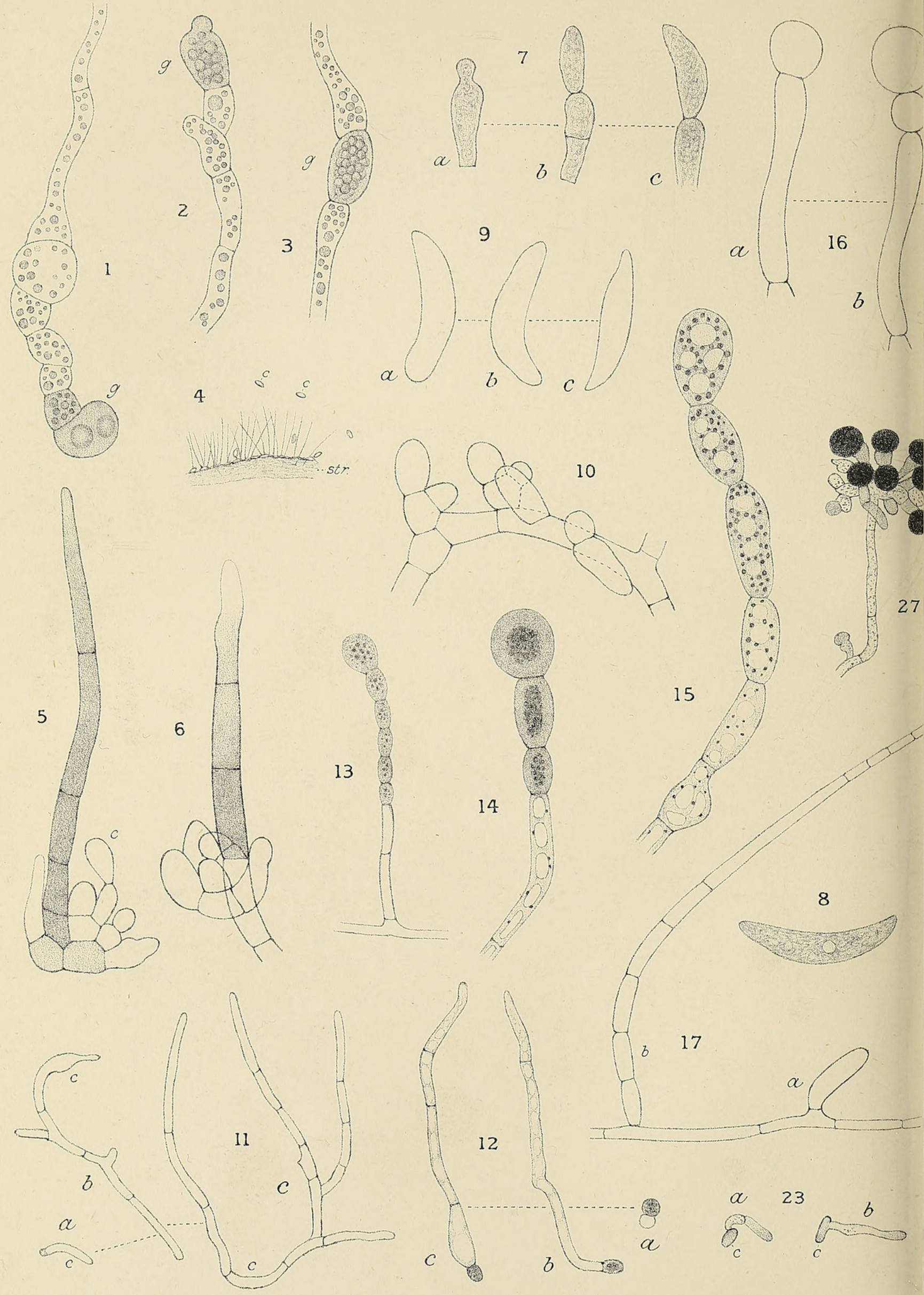

F. Went del.

WENT. - SUGAR-CANE DISEASES. 
Vol.X, PL.XXVI.

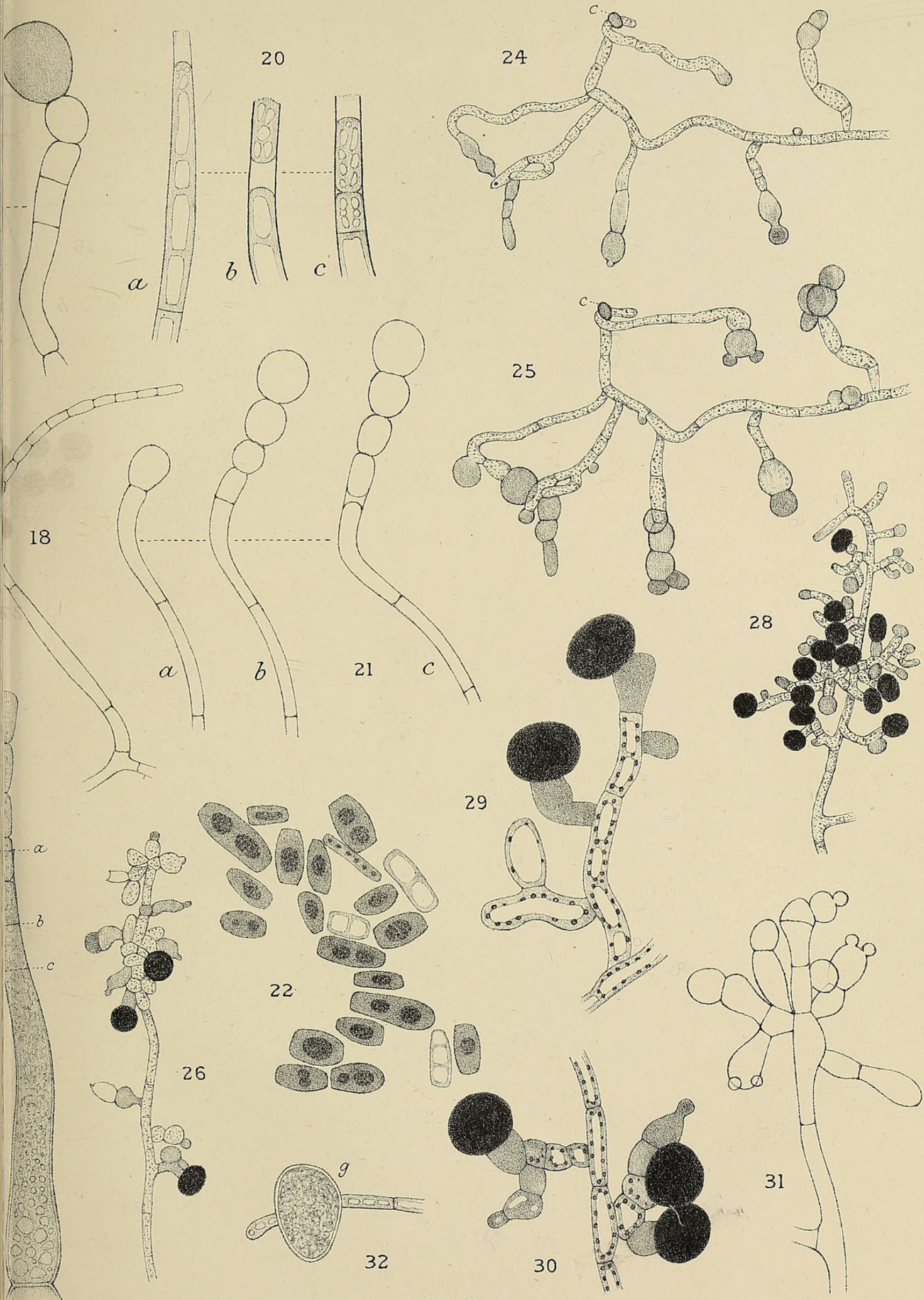

University Press, 0xford 

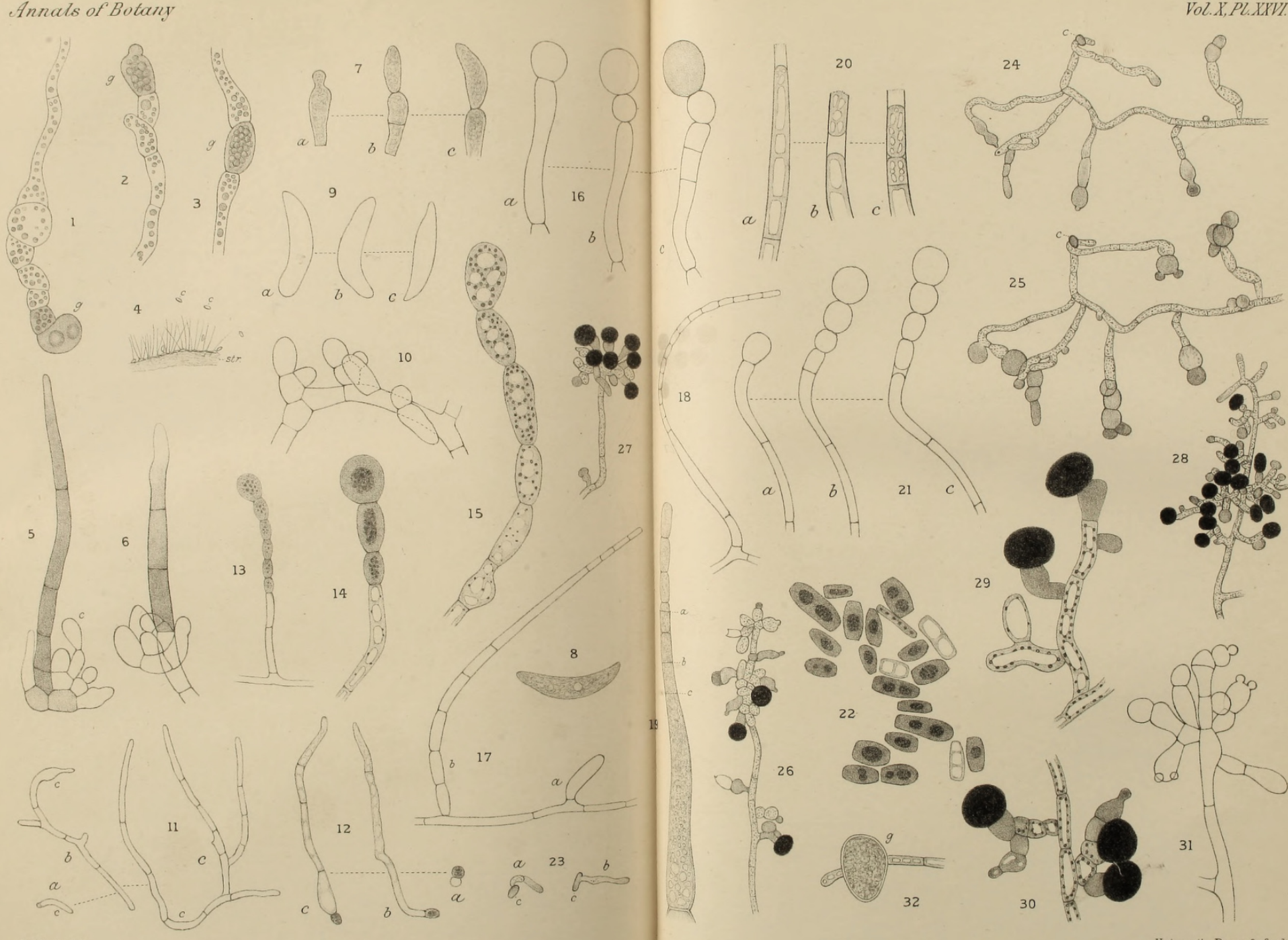

F. Went del.
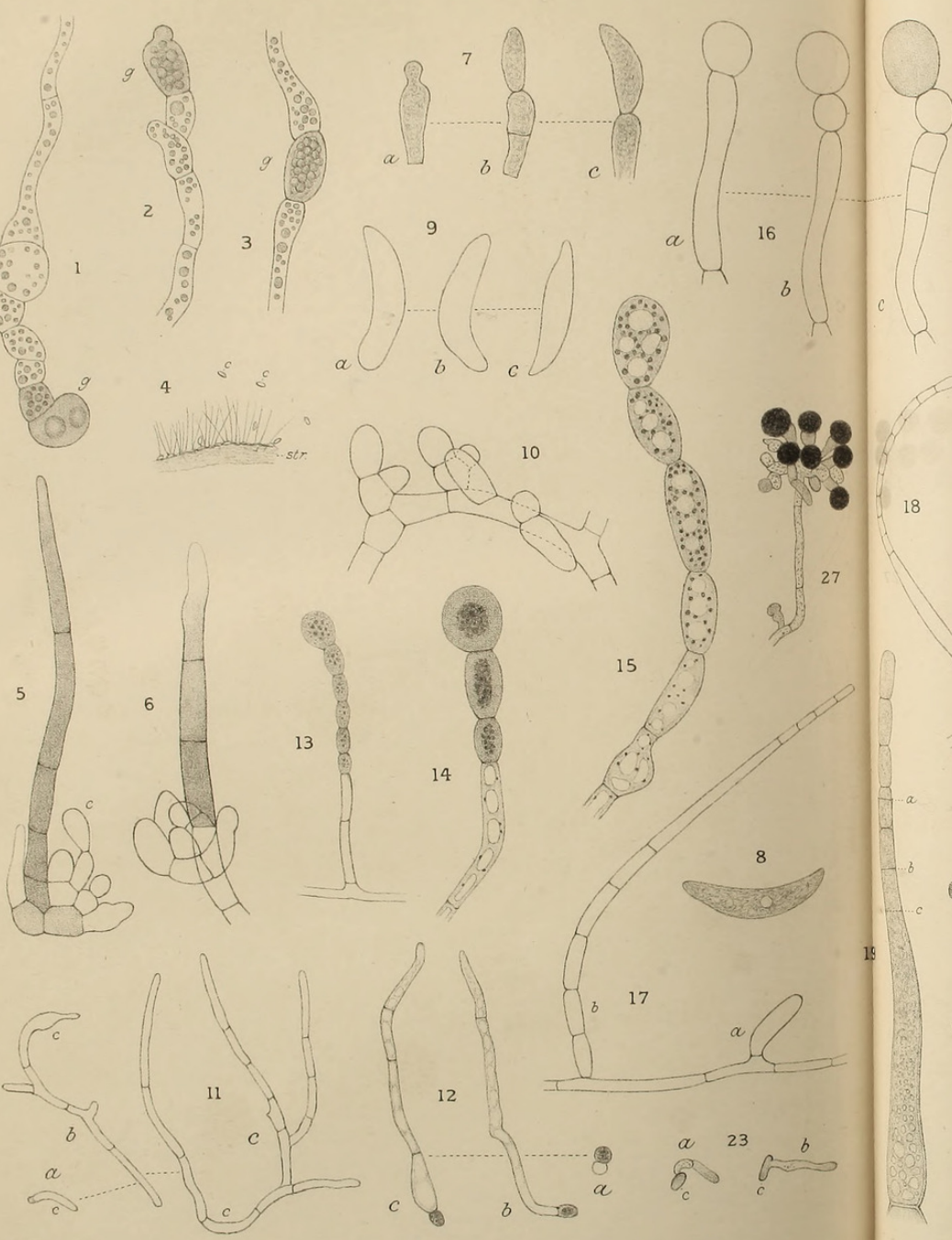

WENT. - SUGAR-CANE DISEASES. 


\section{$2 \mathrm{BHL}$ Biodiversity Heritage Library}

Went, F. A. F. C. 1896. "Notes on sugar-cane diseases." Annals of botany 10, 583-600. https://doi.org/10.1093/oxfordjournals.aob.a088627.

View This Item Online: https://www.biodiversitylibrary.org/item/235772

DOI: https://doi.org/10.1093/oxfordjournals.aob.a088627

Permalink: https://www.biodiversitylibrary.org/partpdf/318439

\section{Holding Institution}

Smithsonian Libraries

\section{Sponsored by}

Biodiversity Heritage Library

\section{Copyright \& Reuse}

Copyright Status: Not in copyright. The BHL knows of no copyright restrictions on this item.

This document was created from content at the Biodiversity Heritage Library, the world's largest open access digital library for biodiversity literature and archives. Visit BHL at https://www.biodiversitylibrary.org. 